\title{
Determinants of Trade Balance in Ethiopia
}

\author{
Mamo Esayas Ambe \\ Lecturer, Department of Economics, Woliata Sodo University, P.O.box .138
}

\begin{abstract}
Ethiopia like other developing countries is highly dependent up on earnings from the sales of primary commodities and concentrating on small range of export commodities and market outlays to finance much needed capital goods imported. Thus, the country's exports have failed to finance its import demand this makes the country to record frequent trade deficit in international trade. So that, investigation on trade balance, its structure, volume and value and the factor that affect it is necessary. The research therefore, aims at dealing mainly with determinant of trade balance in Ethiopia and investigating the structure, value, volume and direction of export and import in Ethiopia. This study uses unit root test, co-integration techniques, Engel-Granger test, and Error correction model.The main finding of this paper are FEA shows a long run negative relationship with trade balance .on the other hand lag trade balance and REER shows a long run positive relationship with trade balance .However, Real GDP is insignificant in the long run. (2) REER shows a short run negative relationship with trade balance. On the other hand Real GDP, lag trade balance, FEA and trade liberalization are insignificant in the short run estimation.The study recommends appropriate attention to be provided for boosting export sector and encouragement of domestic output expansion coupled with using technology in the production of output for domestic as well as international market.
\end{abstract}

Keywords: trade balance, export promotion, economic growth

DOI: $10.7176 /$ RJFA/10-3-06

\section{CHAPTER - ONE}

\subsection{Background of the Study}

International trade has been going for thousands of years. Different thinkers have been writing lots about the causes of international trade. including the merchandise idea, which missed the main point of what trade is all about and there by failed to recognize that its conclusions were valued only in certain cases rather than in general (Willian Son, 1982), lots have been said on the issues.

It is clear that every nation is operating in international trading system. An international trading transaction takes places because someone in one country has something that some on another want to buy. Nature has also endowed different countries with different resources. The differences among countries in terms of natural resources oblige countries to involve in international transactions of good and service. Though, Ethiopia is a country endowed with favorable environment and enormous natural resources, the country's involvement in international trade is inevitable and very important for its development; accordingly, the country has been involving in the system (Tura, 2001)

With the country moving towards market-oriented economic system, trade reforms as an integral part of the structural adjustment program have been implemented. Essentially, the policy regime has shifted from a controlled regime towards 'more liberalized' one. By so revising its trade and exchange rate regimes the country was adjusting its trade to the rest of the world, which was globalizing at a fast pace, and the international monetary fund inspired and supported structural Adjustment program(EEA Annual Report,2001).

In their effort for faster economic growth, developing countries heavily depend on import or capital goods and intermediate goods from developed countries. To finance their import, they depend on their export earning. However, developing countries export sector is characterized by fluctuation in both value and volume and this instability restraint the economic growth of developing countries. In addition, as some portion of their GDP is derived from trade, developing countries are high vulnerable to the external world (Ibid).

As we said above developing countries experience fluctuation in the price of their primary exports. The main reasons for this according to Salvatore (1998) are inelastic demand and unstable supply. The demand for primary exports of developing nations is price inelastic since households in developed nations spend only a small proportion of their income on primary commodities. And on the supply side, the supply of the primary exports of developing nations is price inelastic because of internal rigidities and inflexibilities in resources used in mast developing nations.

On the other hand, developing countries are importing those commodities whose prices are increasing over time. Hence the foreign earning they get from their deteriorating exports will not be enough to cover their import .Adding to this; their import demand is increasing over time, which will worsen the situation. Thus, the problem faced by developing countries could be judged from their economic interaction with others countries and this interaction is reflected in the country's Trade balance. This being the case, we could argue that, for many developing countries the Trade balance has not been satisfactory. Ethiopia is one of the developing 
countries cannot escape this fact(Ibid).

In spite of those various policy measures, growth in revenue from export was not only unstable but also failed to match the increase in volume (Annual Report on the Ethiopia economy, 1991/00). Moreover, basic structure of the Ethiopia is export remain unchanged.

On the contrary, the country's import as percentage of Gross Domestic product (GDP) has sharply increased from $4.7 \%$ in $1950,9.5 \%$ in 1996 and $9.2 \%$ between 1970 and 1974 (sheferawe,1995) to 13.5\% and $24 \%$ of GDP in 1992/93 and 1999/00 respectively (NBE,2001).Import as percentage of GDP keep on increase like, 26.4\% and 30.4\% of GDP in 2006/07 and 2007/2008 respectively (NBE,2007/08). As a result, Ethiopia trade deficit increased on average per annum by $2.3 \%$ during the period of 1967/68-1973/74 (Equar,2001).In a similar way, the deficit increased on average per annum by $8.5 \%$ and $12.7 \%$ during the period 1985/86-19991/92 and 1992/93-1999/00 respectively (NBE,Annal Report). Reflecting a continuous surge in imports, which more than offset the considerable rise in exports, merchandise trade deficit widened from USD 3.59 billion (23.7 percent of GDP) in 2005/06 toUSD3.94billion(20.3 percent of GDP)in 2006/07 and further to USD 5.34 billion (23.8 percent of GDP) in 2007/08 (NBE, annual Report).

\subsection{Statement of the problem}

Least developed countries (LDCs), besides their poor economic performance are often exposited to trade deficit ( the value of good and service they export is by far less than the value of good and service they import). For instance, widespread balance of payment (Bops) crisis of the 1980 which in turn resulted in a serious debt problem, hit many LDCs This situation increased their need for higher export receipt (Tura, 2001).

The situation in Ethiopia is not different from that of other LDCs. The country apart from being the poorest nation in the world is running a persistent trade deficit The main reason for such deficit is its commodity concentration (exceedingly high depend on a agriculture exports, coffee in particular) and geographical market concentration (export and import concentration mainly on Europe, north America and Japan) on the hand and import of basic goods on the other hand (Alemayehu, 1999). Basically, there has been no decline in the dependency level of primary commodities. In other word no shift towards the export of semi-processed or manufactured goods this implies the earning from export is very law and unable to cover to import need of the country.

The country has implemented several foreign trade reforms with the objective of encouraging export and liberalizing import since 1992 (Mulu and Tarekgn, 1999). Consequently, the previous restrictive trade policies have been relaxed, various measures have been taken since Oct 1992, subsequent to the initial measures of devaluation of national currency. In spite of these facts, Ethiopia has never experienced surplus trade balance in its history except in 1972/73 and 1973/74 (NBE reports, various issues). More specially, the trade deficit of the country as a percentage of GDP widened by 58\% from an average of $8 \%$ during the per- reform period relative to $13 \%$ of the post reform period (Annual Report on the Ethiopia economy, 1999/00).

However ,the country implemented several trade reforms, it is still running a persistent trade deficit .This implies, the existence of internal and external factors that may affect the trade balance of the country from the internal point of view, different literature Stated that GDP of the country, trade liberalization, Natural obstacles to trade (transportation cost), foreign exchange availability, exchange rate, and government policies as determinant factors. The availability of foreign exchange rate and the rise in national income of the country may encourages the demand for import and thereby deteriorate the trade balance Alemayehu (1999) also noted that commodity concentration and market (geographic) concentration as factors that make the trade balance of the country worsen.

The external factors involve international and individual country's trade and related policies. The rules established by international organizations such as the world Trade organization (WTO) may in the long run promote external trade. In the short run however, the degree to which globalization pressurizes developing economies to open up without allowing enough time to prepare for the challenges, could have a serious repercussion on their export performance (World Bank policy research paper, 2002). The protective polices of countries through tariffs and now tariff barriers, such as agricultural polices of some European countries under pressure from internal industries constrain exports of developing countries (Shafadin, 2002). The world income also affects the trade balance of the country positively through encouraging exports.

Thus, because of the above mentioned and other related problem, the Ethiopian Foreign trade sector is unable to play most of its major role in the development process of the country. It is this scenario that initiates me to do this research.

This study, therefore, is intended to deal with those factors that influence the countries trade balance.

\subsection{Objective of the study}

The general objective is to investigate the determinant of Trade balance in Ethiopia.

The specific objectives of the study are:- 
- To assess trends in Ethiopia trade balance.

- To give highlights on policies and measures taken by the government to deal with the problem in both sector.

- To forward policy recommendations as a solution for the problem.

\subsection{Significance of the study}

Being one of the poorest of LDCs Ethiopians export is dominated by few agricultural primary products and has been controlled with structural rigidities and demand side problem. Since an expansion in import has to be matched by the corresponding expansion in exports it needs a closer look at it.

Therefore, by identifying the determinants of the trade balance, the study may help in designing measures to improve the country trade deficit. It is important to note that this study is not the beginning in the study area.

\subsection{Scope of the study}

The study is delimited to the different macro- economic variable that is affecting trade balance in Ethiopia The coverage in terms of time span will be determined based on the availability of data source on majority of the explanatory variables. For the explanatory part the research is cover the time span of 1971/72- 2007/08 E.C This period is chosen due to the availability of reliable data.

\subsection{Methodology of the study Data Sources}

This study employ secondary data obtained from different institutions such as, Ministry of Finance and Economics Development (MOFED), National Bank of Ethiopia (NBE), customs authority and central statistics Authority. For general descriptive analysis the study use processed data from international journals, magazines, periodicals, different websites which are related to the study and different publication.

\section{Method of data analysis}

The methodology for analyzing the data includes econometrics regression analysis and descriptive tools like simple statistical tools, table, figures and percentages. With appropriate economic classification, economic analysis was made and inference was drawn from the result obtained in the discussion. Econometrics analysis is used to gather the factors that affect trade balance.

\subsection{Hypothesis}

At the end of this study it is expected that the sign of each variables as follows:

- Lagged trade balance is negatively related to the trade balance due to the adverse effect of the previous year trade balance on the current trade balance.

- The foreign exchange availability is negatively related to trade balance this is because the availability of foreign exchange is expected to encourage import and there by bringing about deterioration in trade balance.

- The gross domestic product (GDP) is negatively related to trade balance this is because the rise income is expected to encourage import and thereby bringing about deterioration in trade balance.

- Real Effective exchange rate is assumed to be positively or negatively related to the trade balance due to the overvaluation or devaluation of domestic currencies .If the domestic currencies devaluated exchange rate are expected to be positively related to trade balance The reverse is true.

- Trade Liberalization will have positive effect on trade balance this is because liberalization removes trade barriers, directing the illegal exports to official channels and increasing the countries Competitiveness in international market

\section{Chapter two \\ ETHIOPIAN FOREIGN TRADE}

\subsection{Foreign Trade polices}

\subsubsection{The Pre-Reform Trade Policy}

Among the policies that have implemented by different governments that ruled the country for the last four decades, the policy adopted in the pre 1991/92 period (both during the imperial and Military government of Ethiopia) was characterized by strongly inward oriented development strategy, which used a prolonged appreciation of the Birr, high tariff rates, extensive foreign exchange control and other non-tariff barriers as well as heavy taxation on exports( Deble G, 2004). These policies are likely to have a detrimental impact on export by influencing directly or indirectly the profitability and competitiveness of exports.

Before the 1974 popular revolution an import Substititution strategy with some export promotion elements was adopted. The regime's trade policy main objectives were to protect domestic industries from external competition (to encourage domestically produced goods). Taxes on exports were reasonable and government 
intervention in the export sector was limited to some regulation and quality control. Tariff and non-tariff measures were used as a policy mechanism to achieve the objectives (Eshetu, 1995). The economic rational of trade policy of the Imperial period was the classical goal of mobilizing government revenue by imposing taxes on exports and imports, maintaining the balance of payment at a sustainable level as well as providing domestic economy with the degree of protection demand necessary (EEA, 1999-2000).

After the coming to power of Derge, despite the fundamental shift in ideological out look, the trade regime was adopted from the imperial government. The exchange trade regime

Was adopted from the imperial government. The exchange rate policy and exchange rate, were left intact as were the systems and institutions governing the states role both in export and import trade; an attempt to closely monitor the price quantity and distribution of goods; giving special emphasis to external trade sectors deemed essential for economic growth and in the trading of medical equipment and goods ensure the Health and security of the population; an attempt to diversity the type and destination of goods externally traded.

Thus, one of the major proposes of the private sector and most importantly the socialization of economic activity. The private importers were driven out of the business while the private exporters were prohibited from exporting traditional commodities. The export of such commodities was taken over by public enterprises created for the purpose.

Berhanu and Befekadu(1999/2000) also summarized the major policy packages governing external trade of the regime as follows:

\# Fixed official exchange rate.

\# Restive foreign exchange licensing system for private use.

* Very high and escalating import tariff made up of several layers and categories with the maximum rate as high as $230 \%$ of its value.

* Reference price schemes for exports, below which export was prohibited and

* Government marketing channels for all imports and major exports.

In Short, almost all the economic activates of the regime were under control of public enterprise, which means centralized .such measures resulted in the country's poor performance of export sector by reducing the competitiveness of the country's exports in the world market

\subsubsection{The post Reform Trade policy}

Ethiopia has after the downfall of the Derge regime undertaken a number measures and reforms to change the structure of the economy and bring about rapid economic growth and development.

Hence in Ethiopia, Similar to other developing countries, trade Liberalization is one of the comprehensive policy reform taken by the transitional government of Ethiopia (TGE) to address the foreign trade problems. The TGE launched the new economic policy in November 1991/92. The reform consisted of transition from command to a market economy Economic stabilization and structural adjustment.

The undertaken policy measured have mainly concerned with the correction of price distortions, lifting of restrictions on private sector, instituting Markets for factors of productions, reducing macro economic imbalance and trade Liberalization (Ministry of Trade and Industry, 1994/45).

The Liberalization measures were initiated by the devaluation of Birr by $142 \%$ (From Birr 2.7 per USD to Birr 5 per USD). The stream ling of administration controls as well as the reduction in tariffs and elimination of Export duties with the exception of that imposed on coffee (EEA, 1999/2000).

As Berhanu and Befekadu (1999/2000) cited, the major foreign trade reforms undertaken by the government are summarized bellow.

- Liberalization of the foreign exchange control. Foreign exchange was to be made available to dully licensed importers through the auction markets.

- Enormously simplifying licensing procedure.

- A supportive service to private exporters is designed in areas of transport, package, training, overseas market research etc.

- The ratification of those goods controlled through the quota system.

- The drastic reduction of custom duties from an average high of $230 \%$ to an average maximum of $50 \%$.

- Elimination of duty on all exportable with exception of coffee.

- Move towards a more market determined exchange rate with the introduction of the auction pricing system.

- Introduction of foreign exchange retention scheme to encourage exports.

- Re-addressing the external sector imbalance and improving the foreign reserve position of the country.

- Issuing a proclamation code that redefined the position of foreign investors giving tight to permit their profits and dividends and to pay related fees, royalties and other foreign exchange costs. The code reserves certain sectors, financial, energy and rail/air transportation. 


\subsection{The Performance and structure of Export}

\subsubsection{The Role and performance of Export}

Foreign trade is one of the major economic sectors which should play significant role in the Ethiopian economy. Thus, there is a need to analyze the performance of and role of foreign trade closely.

The performance of Ethiopian export was sluggish over the period of mid 1970-mid-1990s. This can be particularly observed if we look at the ratio of export to GDP and to imports as well as its contribution in the world market. Accordingly, export as a percentage of GDP that registered on average $8.86 \%$ in the second five years of the 1970 s declined successively to $6.65 \%, 5.62 \%$ and $4.28 \%$ during the period of $1980 / 81-84 / 85$, $1985 / 86-89 / 90$ and $1990 / 91-1994 / 95$ respectively and $7.42 \%$ and $8.13 \%$ during the period of $1995-200 / 01$ and 2001/02-2007/08 respectively (Table 3.1)

$\begin{array}{lccc}\text { Table: 3.1 percentage of export (EXP) to DGP, Import to GDP and Exp/imp } & \\ \text { Year } & \text { Exp/GDP } & \text { Imp/GDP } & \text { Exp/imp } \\ 1975 / 1976-1979 / 80 & 8.86 & 11.12 & 71.12 \\ 1980 / 81-1884 / 85 & 6.65 & 16.52 & 47.02 \\ 1985 / 86-1989 / 90 & 5.62 & 15.4 & 39.68 \\ 1990 / 91-1994 / 95 & 4.28 & 14.82 & 28.8 \\ 1995 / 96-2000 / 01 & 7.42 & 23.6 & 35.4 \\ 2001 / 02-2007 / 08 & 8.13 & 32.5 & 24.9\end{array}$

\section{Chapter -three}

\subsection{Econometric Methods}

\subsubsection{Model Specifications}

Trade Balance at the aggregate level, Specified at the function of some relevant variables was employed in the econometric modeling of the level of trade balance. Therefore, the model is mainly concerned with identifying the elasticity of trade balance in Ethiopia with respect to its main determinants.

In specifying the trade balance models, it is hypothesized that trade balance is to be dependent on the lag trade balance (TBlag), Real output (RGDP), Real Effective Exchange Rate (REER), foreign exchange available (FEA), Trade liberalization (LIB or dummy).

Therefore in this particular study the trade balance function will have the form:

LTB = F (LTB t-1, LRGDP, LREER, LFEA, LIB) or

$\mathbf{L T B}=\beta_{0}+\beta_{1} \mathbf{L T B}_{\mathrm{t}-1}+\beta_{2} \mathbf{L R G D P}+\beta_{3} \mathrm{LRGDP}+\beta_{4} \mathrm{LFEA}+\beta_{5} \mathrm{LIB}+\mathbf{e}$

Where $\mathrm{TB}=$ Trade balance defined as the ratio of export to import.

TBt-1 = lagged trade balance

RGDP $=$ Real output of the country

REER $=$ Real Effective exchange rate

FEA $=$ Foreign exchange availability

LIB $=$ Trade Liberalization

$\mathrm{e}=$ Error term

\subsection{Explanation of the variables \\ The Dependent Variable}

Usually Trade balance is measured by the difference of value of total export and value of import. In this study, trade balance is measured as the ratio of export value $(\mathrm{x})$ to import value $(\mathrm{M})$. The ration of $\mathrm{X}$ to $\mathrm{M}$ (i.e. $\mathrm{X} / \mathrm{M}$ or its inverse has been widely used in many empirical investigation of trade balance exchange rate relationship, such as Bahmani-oskooee and brook (1999), lowinger (2001) and onafoowora (2003). This Ratio is preferable because it is not sensitive to the unit of measurement and can be interpreted as nominal or real trade balance (Bahmani-Oskooee, 1991). The other reason is since negative number is not transformed in to log trade balance as a ratio of export to import is used for regression.

The Explanatory variables

1. Lag trade balance (TBlag): The inclusion of this variable is based on the argument that the deficit in previous year affects the current trade balance as it is financed by the next subsequent years and disturbing the trade balance equilibrium. This is what is expected.

2. Real output (RGDP): The inclusion of the real output is based on the argument that the growth in GDP of a nation leads to an increase in demand for manufactured goods (which have high income elasticity of demand). The growth in real GDP has a positive influence on Ethiopian imports, which adversely affected its trade balance (Tura, 2001) and (Muluneh, 1982).

3. Real effective exchange state (REER): The specification of trade balance model to handle real effective exchange rate is based on the premise that depreciation of the currency has great impacts to economic 
development. One of the prominent impacts is the marshal-Lerner condition, which represents that real depreciation leads to increase the trade balance in the long run if sum up value of import and export demand elasticity exceed one. Herman Rincon (1999) examined the relationship between trade balance and exchange rate test for marshal- Lerner condition. His empirical results provided significant evident for the marshal-Lerner condition.

4. Foreign exchange availability (FEA): The inclusion of foreign exchange availability on this model is based on the argument that availability of foreign exchange is encouraging import and there by bringing about deterioration in trade balance. Tura (2001) form exchange receipts and lagged official reserves have a positive and significant influence on imports. Thus, the variable is expected to be negatively related to trade balance.

5. Trade Liberalization (LIB): The inclusion of this variable in the model is based on the premise that trade liberalization is expected to improve the trade balance by reducing tax and tariff and also by providing different subsidy.

\subsection{Estimation Results and Analysis}

3.4.1Time Series Characteristics of the Data

Table: 4.4 Dickey Fuller Test

\begin{tabular}{|c|c|c|c|c|c|c|}
\hline \multirow{4}{*}{ Variables } & \multicolumn{6}{|c|}{ Dickey Fuller Class Test } \\
\hline & \multicolumn{2}{|c|}{ Dickey Fuller } & \multicolumn{4}{|c|}{ Augmented Dickey Fuller } \\
\hline & \multicolumn{2}{|c|}{ Lag lengths } & \multicolumn{2}{|c|}{ Lag Lengths -1 } & \multicolumn{2}{|c|}{ Lag Lengths -2 } \\
\hline & Constant & Trend & Constant & Trend & Constant & Trend \\
\hline DLTB & $-6.606 * *$ & $-6.505 * *$ & $-5.270 * *$ & $-5.021 * *$ & $-4.569 * *$ & $-4.473 * *$ \\
\hline DLTBt-1 $_{\text {t }}$ & $-7.175 * *$ & $-6.360 * *$ & $-5.982 * *$ & $-4.982 * *$ & $-5.020 * *$ & $-5.064 * *$ \\
\hline DLRGD & $-5.145 * *$ & $-5.588 * *$ & -0.3145 & $-3.7775^{*}$ & -0.08640 & $-3.6680 *$ \\
\hline DLREER & $-4.045 * *$ & $-3.928 * *$ & $-8.047 * *$ & $-3.959 * *$ & $-5.477 * *$ & $-5.405^{* *}$ \\
\hline DLFEA & $-5.695 * *$ & $-5743 * *$ & $-3.754 * *$ & $-3.718 * *$ & $-3.819 * *$ & $-3.974 * *$ \\
\hline
\end{tabular}

** And * refer to significance level of $1 \%$ and $5 \%$ or $99 \%$ and $95 \%$ confidence interval.

Prior to performing any meaning full regression with the time series variables, it is essential to test time series characteristics of the data and hence to establish their order of integration. The variables used in the analysis need to be stationary and/or should be co-integrated in order to infer a meaningful relationship from the regression. This involves unit root tests or exploring the time series properties of the variables by using the standard dickey-fuller (DF) and augmented dickey fuller (ADF) statistics. This is testing whether the sample data used for each variable exhibits stationary or non-stationary trend along a constant mean or trend first by including a constant only and then by including both a constant and the time trend. Here the null hypothesis (Ho) is a series contains a unit root (non-stationary) stochastic trend) against the alternative stationary (deterministic trend). This test has conducted for each variables First at level and then in their first difference. The test conducted with the variable in level indicates that no variables are stationary except for some the ADF statistics result in table 4.4 shows that the null hypothesis of a unit root test rejected for all variables with the exception of real GDP with a constant/drift term included. However, when the trend term is included the null hypothesis is rejected for Real GDP at 5\% significance level for both lag 1 and 2.This indicate that including trend term improves the stochastic nature of the data. Thus, we can conclude that all the variables are integrated of order one (1) with a trend term.

Following the examination of the unit root characteristics of the variable, both the long run and the short run growth impact of the variables used in this study are estimated as already known the Engel-Granger single dynamic model procedure is used to estimate the long run parameters while the short run estimation is carried which involves simplifying the model into more interpretable (parsimonious) characterization

\subsubsection{The long Run Trade Balance Equation}

The Engle-Granger single dynamic long run parameters estimate starts from testing the appropriate lag length of the variables in the model. The WALD test of the solved static long Run Equation is $\operatorname{chi}^{\wedge} 2(5)=86.3541$ $(0.0000)^{* *}$.This implies that lag two is the appropriate lag length for long run estimation at $1 \%$ significance level.

In the estimated trade balance equation, the parameters real effective exchange rate and foreign exchange availability have the expected sign in line to economic theory. On the other hand, the parameters of lag trade balance has unexpected sign against the economic theory this may be due to the shortage of the lags year so it needs more investigations. In addition, the test of significance shows that lag trade balance, real effective exchange rate and foreign exchange availability are significant at $1 \%$ and $5 \%$ level of significance. However, real gross domestic product and trade liberalization are found to be insignificant.

On the other hand the multivariate system diagnostic test of the residuals (shown in the lower block of Table 4.4) indicates that the model has the desirable property of OLS estimation. Test for serial correlation (AR Test), which is used to check whether the error terms are correlated to each other or not, indicates non-existence 
of serial correlation in the trade balance function. The result of hetroscedasticisy test (ARCH test) of the residuals also does not show evidence for autoregressive conditional hetroscedastic errors which it present would result in biased variance of estimates and would also be made the least squares estimates inefficient.

The jargu-Bera test of skew ness and kurtosis of the residuals revealed normality implying the absence of outliers in the data. The Ramsay's regression specification error test (RESET), on the other hand, provides no indication that the function form of the long run model is inappropriate the model is appropriately specified.

Table: 3.2 The long run OLS estimation

\begin{tabular}{|c|c|c|c|}
\hline & Coefficient & t-value & Part. $R^{\wedge} 2$ \\
\hline Constant & 4.0358 & 3.30 & 0.2730 \\
\hline LTBlag & 0.5927 & 4.87 & 0.4503 \\
\hline LRGDP-1 & -0.0974 & 0.899 & 0.0271 \\
\hline LREERI-1 $_{1}$ & 0.2371 & -2.76 & 0.2108 \\
\hline LFEA-2 & -0.2671 & -3.04 & 0.2422 \\
\hline dummy & -0.0269 & -0.236 & 0.0019 \\
\hline 0.201056 & 1.17227689 & & \\
\hline $\mathrm{R}^{\wedge} 2 \quad 0.829511$ & $28.22[0.000]^{* *}$ & & \\
\hline log-likelihood $\quad 9.7741$ & $5 \mathrm{DW} \quad 2.02$ & & \\
\hline no. of observations 35 & 5 no. of parameters 6 & & \\
\hline mean(LTB) $\quad 3.692$ & $3 \operatorname{var}(\mathrm{LTB}) \quad 0.196456$ & & \\
\hline
\end{tabular}

AR 1-2 test: $\quad \mathrm{F}(2,27)=0.47079[0.6295]$

ARCH 1-1 test: $F(1,27)=0.90511[0.3499]$

Normality test: $\mathrm{Chi}^{\wedge} 2(2)=1.7126[0.4247]$

hetero test: $\quad F(9,19)=1.0206[0.4587]$

Not enough observations for hetero-X test

RESET test: $\quad \mathrm{F}(1,28)=1.9852[0.1699]$

ECM [1974 to 2008] saved to Data3

We tested the order of integration of residuals using ADF statistics and the result indicates that we can reject the null hypothesis of non-stationery that is the residual is stationary of I(1) order (result is presented in Annex D).

The Durban Weston (DW) test shows that the variables are highly co-integrated in the long run.

\subsubsection{Dynamic Specification of Trade Balance}

Having already obtained the long run model and estimated the coefficient, the next step will be estimating the coefficient of the short run dynamics that have important policy implication. Hence an error correction model (ECM) will be estimated that incorporate the short term interactions and the speed of adjustment towards long run equilibrium. Since all variables in the model are now I (1), statistical inference using standard $\mathrm{T}$ and $\mathrm{F}$ tests are valid. The estimation result is reported below.

Table: 3.3 Modeling the Dynamic of Trade balance by OLS.

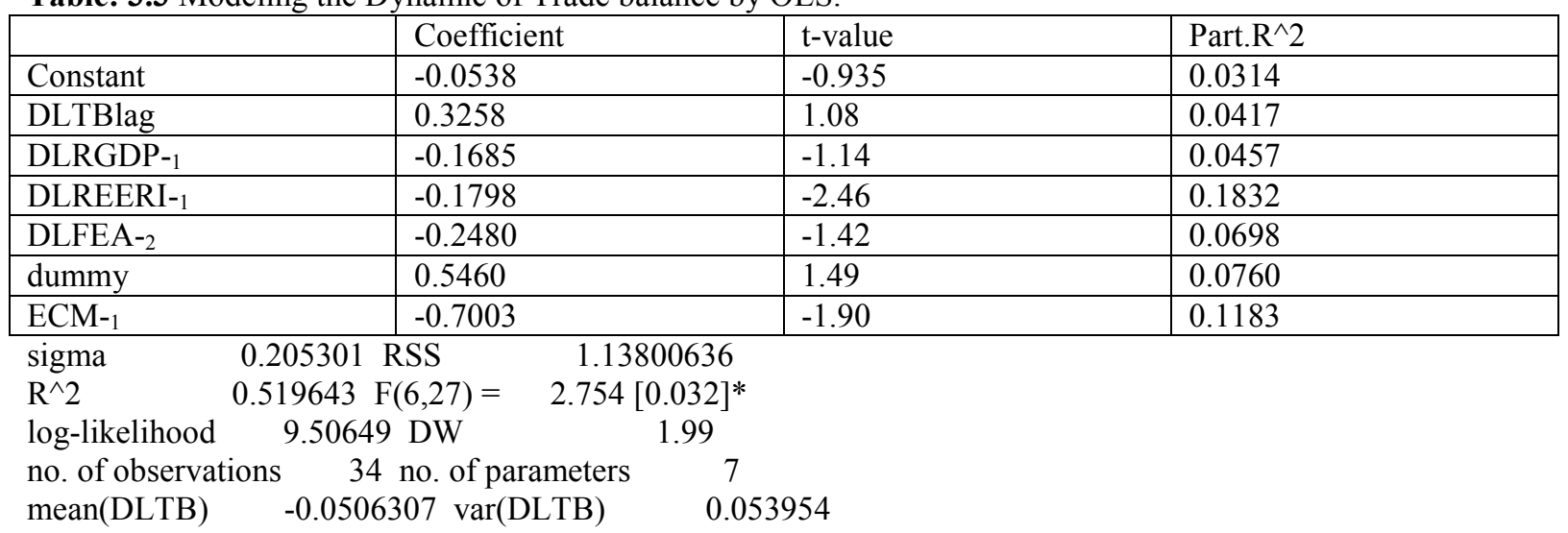

AR 1-2 test: $\quad \mathrm{F}(2,25)=0.73861[0.4879]$

ARCH 1-1 test: $F(1,25)=0.036110[0.8508]$

Normality test: $\mathrm{Chi}^{\wedge} 2(2)=2.5898[0.2739]$

hetero test: $\quad F(11,15)=0.36070[0.9531]$

Not enough observations for hetero-X test

RESET test: $\quad \mathrm{F}(1,26)=1.6812 \mathrm{e}-005[0.9968]$

Note: ECM-1 lagged co-integrating vector saved from the estimated long-run equation.

The results reveals that all the variables included in the dynamic short run model except, lagged trade balance, real GDP, FEA and Trade Liberalization are significant. Though they are insignificant, they are retained 
in the short run in order to model the system (Harris 1995:136). The speed of adjustment has a negative sign and is significant with a fairly magnitude (-0.70). Its magnitude indicates that the $70 \%$ of the disturbance in the short run will be corrected each year, the coefficient of determination (R2), indicates that $51.9 \%$ of Trade balance is explained by the variable included in the regression. The overall significance, F-test, established shows that the explanatory variables jointly explain trade balance significantly which is different from zero at $5 \%$ significant level.

Similarly to that of the long run, the multivariate system diagnostic test of the residuals (Shown in the Table 4.3) indicates that the model has the desirable property of OLS estimation.

\subsection{Economic Interpretation of the Parameters}

We begin discussing the condition variables; real GDP and trade liberalization are insignificant in both the long run and short run. Lagged Trade balance significant in the long run but insignificant in the short run. The rests are significant both in the long-run and short-run.

Theory predicted that the trade balance of the country in the last year has effect on the current year trade balance. The lag Trade Balance is insignificant in the short run. However, it is significant and positive in the long run. This result is contrast to the expected hypothesis at the initial time.

The impact of real GDP on Trade Balance is Negative in the long-run, Because It is obvious that, the growth in Real GDP (National Income) of a nation leads to an increase in demand for manufactured goods (which have high income elasticity of demand) and a decline for primary products (Which have low-income elasticity of demand),this result is consistent with the finding of Tura (2001) and Muluneh (1982) they found that, the growth in real GDP has a positive influence on Ethiopian imports, which adversely affected its trade balance. However, in the short run the effect of real GDP on trade balance is insignificance.

The result shows us that the effect of real effective exchange rate on the trade balance is positive and significant in the long run. This is because firstly, increase quantity of exports. Deprecation of the currency reveals the domestic goods cheaper as compared to the foreign goods, thus making export more competitive. Secondly, quantity of imports decrease, as import is relatively more expensive. So that, the Marshall-Lerner condition is fulfilled. This result is consistent with the finding of shirvani and wilbratte (1997).

In the short run, the effect of REER on trade balance is Negative and Significant. This is because trade balance may be worsening first due to decrease in value of export and increase in value of import of improves after some time. This is referred to as the J-curve.

In the estimation result the effect of foreign exchange availability on trade balance is negative and significant in the long-run. But it is insignificant in the short run This result is consistent with the findings of Tura (2001) that exchange receipts and lagged official reserves have a positive and significant inference on imports.

Finally, the effect of trade liberalization on the trade balance in the long run is insignificant. This result is similar to that of Santos Pauline and Thirwall (2004) that showed that for the period 1972-1997 Trade liberalization worsened the trade balance of developing countries. They also showed that trade liberalization caused both import and export grow faster, but the growth of import was faster than that of export for a panel of 12 developing countries. However, the effect of trade liberalization on the trade balance in the short run is insignificant. This result is consistent with the expected hypothesis.

\section{Chapter four}

\section{1 conclusion}

Many empirical studies show that LDCs have been marginalized from world economy and from international market because of the structure, composition, and performance of their trade (particularly of their export sector). Ethiopia is a typical of such countries where the majority of the export earnings come from agricultural sector in the form of raw materials and semi processed commodities.

The finding of the study shows that the composition of Ethiopian exports remained the same in the both the Derge and in the post reform period although relative share of the various agricultural exports had changed. Coffee has been a major commodity for about of the total average export earnings in the periods between 1980/81 and 2007/08. However; both the value and volume of export have a significant increment in the post reform period.

The study has also tried to show the trend in the country's commodity and geographic concentration. In this period under discussion the study showed that the country was highly dependent on few primary agricultural commodities i.e. high commodity concentration this Trend is continued also in the post reform period. Moreover, Ethiopia's export sector in those periods can also be characterized by geographical concentration. Major portions of the export which are mostly agricultural products go to Europe (particularly to Germany, UK and France); USA and to Asian countries such as Japan and Saudi-Arabia.

Thus the country's export had confined to a few industrial countries that are price makers in the 
international market. Specifically trade with African countries is very much limited.

With regard to imports, the study revealed that the country has been importing many items and the trend showed that Ethiopia is highly import dependent and has been importing strategic goods and other like finished and semi-finished good the price of which are high in international market.

Following the trade reform program by the current government the assumed benefit of the country from the export sector, has constrained by both internal and external problem such as the long term decline in price level in the international market, low price, and income elasticity demand for Ethiopia exports, unfavorable demand for such primary products, high commodity and market concentration, trade policies in both developed and developing countries and so on.

\subsection{Recommendations}

Export diversification towards high potential areas should be extended since Ethiopia has various advantages for the development of its export sector. These include the abundant and capable labor Force; low wage level; a wide range of weather and soil conditions; preferential access to European market and proximity to the middle East markets. Moreover the preferential access to the common market for eastern and southern African states (COMESA) with a total population of more than 260 million also offers substantial market opportunities for several export items for the country.

Policies that enhance the diversification and facilitate the shift towards the export of semi processed and manufactured goods are essential. One obvious option in this case is to make huge investment in the export sector through a coordinated effort between the private sector and the government. Moreover, policies that diversity the destination of export to new inroads, in addition to the already existing is also essential.

As implication, in order to achieve the desired effects on trade balance, Ethiopia should depend on policy that focusing on the variable of real exchange rate, which is the nominal exchange rate to aggregate price level. At the same time, the devaluation-based policies (affected through changes in nominal exchange rate) must cooperate with stabilization policies (to ensure domestic price level stability) to achieve the desired level of trade balance.

Create awareness among the people to change their attitude towards domestic products which is highly in favor of foreign product goods.

Rationing the available foreign exchange that is allowing foreign exchange only for necessary products.

Moreover creation of appropriate legal and institution framework and environment capbel to boost the expansion of export sector and enhancing the effective and efficient use of imported goods and service for encouraging in export items production.

\section{References}

* Ahumed N.(2000), Export response to trade liberalization in Bangladesh a cointegration analysis, Applied Economics, 2000, 32, 1077-1084.

* Alemayehu Geda and Birhanu Gega (1999), The Ethiopia Economy performance and Evaluation, Proceeding of the Eight Annual conferences on the Ethiopian Economy, Nazerth, Ethiopian.

* Bahamani-askooe,M (2001), Nominal and real Effective exchange Rates of middle eastern countries and their trade performance, applied Economic 33. PP 130-111

- Baharmshah A.Z (2001, The effect of exchange rate on bilateral Trade balance Evidence from Malaysia and Thailand, Asian economic Journal, Vo115.

* The Columbia Encyclopedia (2004), 6 Edition:Columbia University press.

* Befekadu Degfe and Berhanu Nega, (2000), Annual report on the Ethiopian economy, volume 1, Ethiopia Economic Association Addis Ababa.

- Douglas ,N (1983), Freight Rates and Economic Development, Journals of Economic History.

* Elias Kedir (1998), Exports and Economic Growth theories And Evidence From eastern and southern Africa's, MSc thesis, AAU.

- Equare Desta (2001) ,Determinant of Real Exchange Rate in Ethiopia, An Empirical investigation (1985 $\left.\mathrm{Q}_{1}-200 \mathrm{Q}_{3}\right) \mathrm{AAU}$.

* Esthetu chole (1995), "Some problem in measurement of import Substitution A critical review of the literature", Ethiopian Journal of Development Research Vol 5-7.

* August in K. fosu(2002), "Export and Economic Growth the African case" world development. 18(6) 83636 University of London.

* G.K Helleiner (1994), Trade strategy in medium term adjustment, world development, 58(6) University of Toronto.

* Geda A .and Degefe B. (2002), Explaining African Growth Performance:

- Gomezand Aluarez (2006), Exchange rate Policy and Trade Balance: A co integrationanalysis of the Argentina experience Since 1962. MPRA paper 51 University. Library of Munich. Germany 